\title{
LOU RAWLS-'YOU'LL NEVER FIND A LOVE LIKE MINE’
}

'Hearing culture' suggests that it is possible to conceptualise new ways of knowing a culture and of gaining a deepened understanding of how the members of a society know each other.' (Erlmann 2004: 3)

My $\mathrm{PhD}$ research had sought to understand the social dynamics at work in multi-racial, post-apartheid youth cultures, focusing on the consumption of a new electronic dance music form, Kwaito. Most of the time extended field research does not play out with the clarity presented in research grants, at committee meetings and within literature reviews. The boundaries between ethnography and life are blurred, the 'bigger picture' of the larger structures and relationships that encompass fieldworkers and their respondents-who may also be or become friends and kinovershadowing the clear cut intentions of research questions. I worked as a DJ in the clubs of Johannesburg during my $\mathrm{PhD}$, very much a part of the social world I was mapping; as a young woman, who had returned 'home' to do this research-I had grown up in the city and was locating this research in the youth cultural space that my friends and I inhabited-my personal trajectory was already entangled in the fieldwork. The sweet alchemy of mixing songs and dancing, the warm intimacy of the afterparty and the come down-these are fertile grounds for the making of relationships between young people. I was beginning to see that the affective combination of music and dance cultures was key to social reproduction. The pleasure of music, experienced in relationship with the dancing body, creates powerful emotional entanglements.

Towards the end of the official fieldwork period, I found myself deeply nauseous at a gig where I was playing. Pregnancy was confirmed soon after. The clean lines of fieldwork, the post-writing-up period and my private life began morphing in ways I had never planned. Research seemed very distant as I sank into the quicksand of new motherhood in Johannesburg, a city that had been great for partying, but now felt isolating and harsh. None of my friends had babies, and to fill the days I found myself spending large amounts of time with my mother-in-law, Brenda. We engaged in the daily practices of domestic life-childcare, housework, gardening-regulated by regular breaks for coffee, a read of Oprah magazine, the soap opera at the end of the day, and always music in between, either on the radio, or a mix CD burned on someone's computer. Lou Rawls' 'You'll Never Find A Love Like Mine' was a favourite. Released in 1976, it's big and romantic, with a sweep-you-off-your-feet orchestral accompaniment.

We talked a lot, memories triggered by songs and my questions as a new member of the kin group. I was compelled by her life story, which had spanned being a member of a large, multi-racial family in 1950s' Durban during the beginnings of apartheid's enforcement of racial segregation, through running away from a difficult marriage to Johannesburg, where she forged connections with a different kind of multi-racial cohort in the jazz and theatre scene 
of the late 1970s. Working as a secretary at the legendary Dorkay House, a performance space and haven for the vibrant black jazz and theatre scene of the 1970s, she made her home in the nearby 'grey areas' of inner city Johannesburg. The influx of people of colour into the city in the late 1970s, coupled with illegal subletting practices, despite the repressive laws of the apartheid regime which had zoned the area as white, made controlling the demographics of the area increasingly difficult and it was informally 'let go'. An increasingly multiracial atmosphere began to characterise the neighbourhoods of Hillbrow, Berea and Joubert Park, so despite being classified as a 'coloured' or mixed race person, my mother-in-law could make a home of relative stability and safety in a cosmopolitan area. The relationship between trans-Atlantic diaspora musical forms and the making of a black South African urban identity in defiance of apartheid's designation of the possibilities for selfhood has been well documented (Coplan 2007). The intersection between Brenda's journey to independence, and immersion in a more exciting and liberatory social world built around performance and music culture-both in the local scene and in her private record collection - was part of this crucial intersection of music and dance culture with an alternative conception of self for urban black South Africans.

That Lou Rawls song always came up. It's one of those songs everyone knows, a classic wedding number, the one that will get the folks on the floor to twirl and jazz.

When I eventually left South Africawith my baby but not her father who could not see himself making a life in London-and tried to start writing, this new information from an unexpected source, from a member of an older generation whose social interactions had also been shaped and formed by a culture of music listening and moving, necessitated a change in my approach, and a revision of the research proposal written long ago. As Brenda's son and I tried to figure out our own reunion, over skype calls and immigration blocks, it was the music that made it sweet, that would temporarily suspend all the pain and blocking. In the flat to which I returned, shared with my sister and some girlfriends, now the aunties of my 18-month-old daughter, the radio was permanently turned to Heart FM, which played a rotation of hits that spanned the decades of popular music. Lou Rawls came on often.

Within a year, Brenda's son had joined us in London, and we began making a life together again. The desire for family and home had overridden familiarity and business interests. Our second child was born not long after. I thought often of that flat in Joubert Park, Johannesburg, of how the music had been key to the reunion that led to the birth of Brenda and Charlie's third child, the father of mine. Lou Rawls would've been there; I knew that from her stories. Her husband, from whom Brenda had fled a few years previously, found her again, and came visiting to the flat as he was now working in Johannesburg while their first two children were with his mother back in Durban. I kept on wrestling with the why and the how. She had left him, escaped with her older children, only to have to hand them back into his and his mother's care when the financial and physical demands of single parenthood were too great for her to cope with. She had managed to make a new life anyway. I felt deeply conflicted by the rupture in her narrative of overcoming the odds to make a new life in Johannesburg, and the way in which her ex-husband had come back into her life. When she told the stories of his coming to her flat, to eat and play records, and how they would start to dance, jazzing around the small living room, I knew that a powerful discourse of 
romantic love was being activated, both in her and in me.

The significance of this discourse, especially prevalent in women, has been identified as a key reason why women stay in, or return to, abusive relationships (Hayes and Jeffries 2013). Brenda's migration from Durban to Johannesburg, like that of so many other female migrants, was a profoundly gendered experience-her body tied into powerful discourses of home and family. When her ex-husband, the father of the two children she misses, re-enters her life as a gentleman caller, coming to enjoy the space of music, food, respite and companionship that she has created, a powerful, fully embodied process is entered that overrides memories of a disastrous past. When Lou Rawls sings 'You'll Never Find a Love Like Mine', he is tending to ideas about love that emphasise its relationship with fate, destiny and the rarity of tender devotion: ideas that are ultimately about how this energy can culminate in a transformation of painful circumstances into the idealised home and family. Lauren Berlant's (2008) exploration of sentimentality in popular culture foregrounds this neglected scene of social practice, though she emphasises that turning to the sentimental can be an escape into feeling, in a social-political context with little opportunity for agency elsewhere.

From my vantage point, I knew that the 25 years following 1976 would see their relationship deteriorate into abuse again after the birth of their fourth child and remarriage, that it would be sustained at points by these musical interludes, the parties where the songs and the dance would animate the romantic love discourse once again. I knew that when the fights were bad, Brenda would 'tune into the music', either literally or in her head, to enter a place that sat more with her idealised vision of how it could have been rather than the reality.
I knew that the decision to leave for a second time, now with grown children, would be made in the midst of a dance, when Charlie's attempts to dance with Brenda at a party following what she described as a 'drunken performance' were met with a resistant, 'no, not this time'. In that moment, the powerful alchemy of music, the discourse of romance and loyalty and partner dancing had been sufficiently disrupted by many more years of experience. Yet the love of the music remained strong, just cut off from its relationship to making a partnership. The lyrics take on new significance now; it is, as she tells me, a realisation that she is enough without him. The parameters in which the lyrics are heard and understood shift again into a discourse of self-love, and a reliance on, and loyalty to, the family that has been made through the unionrather than the union itself. The songs that oiled her reunion with Charlie were those to which she turned when she needed refuge from his drunken rages when the romance turned bitter again, those in which she celebrated her emancipation, and commiserated in other losses. Songs can have an adaptive trajectory along the life course.

As I grappled with writing this story, it was in listening to the song that memories could be provoked and past times revisited. Affect refers to processes of life and vitality which circulate and pass between bodies and which are difficult to capture or study in any conventional methodological sense (Blackman 2013). Music here was a lubricant, well oiling the circulation of life and vitality passing between bodies so that connection becomes seamless, effortless. The components of the process-discourses of romantic love, home, family, music, dancing, cooking-become impossible to separate; they exist with and through each other. I imagined that small flat in inner city Johannesburg in the 1970s, the smells of curry or stew being cooked, 
the sparse but meticulously neat furniture, the view down to the grid-like streets below, the threat of police raids on people of colour ever present in this ostensibly white area. Although it was, through the sheer weight of human presence, being left alone by the authorities, it must've left a sense of delayed violence hanging over daily life. Then there was the significance of the musical soundtrack, of black musicians from the USA and South Africa making music that celebrated love and pleasure and urged the body to dance despite hardships and impositions. I imagined I could see Charlie, putting down his quart of beer after dinner to lean over and set the needle on the record, or perhaps it was Brenda who decided to play the song; either way, Lou Rawls would fill the room, animating it with a lush and sensual ambience, imbuing the space with a romantic significance that could not be present in the same way without this aural energy. I only had to look at my own young family, descended from the son they conceived in this time, to see the results of music's intersection with biological and social reproduction in a discursive context which places high value on romantic love, making home and making family.

Veit Erlmann's recollection of the way in which listening and sound might be incorporated into ethnographic accounts urges close attention to what he calls the 'materiality of musical communication' (2004: 2). In this piece I have considered the materiality of musical communication as an experience of intimacy, embodied in the dancing and spatial enhancement that accompanies playing 'You'll Never Find a Love Like Mine', by Lou Rawls. The intimacy of the listening-dancingromantic moment is located in a continuum of mediations inherent in production and listening practices, and how they act to construct space in particular ways (Samuels et al. 2010) The journey from song writing, to studio, to vinyl plant, to music shop, to the record player in the lounge of the flat, the act of placing the needle on the record to intentionally create a rich aural environment is embedded in a complex series of exchanges. To listen-dance-relate in this way generates a powerful immediacy, a utopia of the present where the injuries of the past recede and the future is uninhibited. Christopher Small (1984) describes the way that music comes up all the time in daily life, woven into the fabric of it, rather than a considered and separate activity, musicking-music is inherently phenomenological in its affect on the unfolding of life courses. Music facilitates social reproduction, is a crucial part of reconciliation, courtship, the re-making of a household, the making of new generations, the sustaining sentimental when other avenues of action seem cut off.

\section{REFERENCES}

Berlant, Lauren 2008. The Female Complaint: The Unfinished Business of Sentimentality in American Culture. Durham: Duke University Press.

Blackman, Lisa 2013. Immaterial Bodies. Los Angeles: Sage.

Coplan, David 2007. In Township Tonight! Three centuries of South African Black City Music and Theatre. $2^{\text {nd }}$ edition. Auckland Park: Jacana Media.

Erlmann, Veit 2004. But What of the Ethnographic Ear? Anthropology, Sound and the Senses. In Veit Erlmann (ed.). Hearing Cultures: Essays on Sound, Listening and Modernity. Oxford and New York: Berg.

Hayes, Sharon and Samantha Jeffries 2013. Why do they Keep Going Back? Exploring Women's Discursive Experiences of Intimate Partner Abuse. International Journal of Criminology and Sociology 2013 (2): 57-71. https://doi.org/10.6000/1929-4409.2013.02.6. 
Rawls, Louis 1976. 'You'll Never Find A Love Like Mine'. All Things in Time. Philadelphia: Philadelphia International Records.

Samuels, David, Louise Meintjes, Ana Maria Ochoa and Thomas Porcello 2010. Soundscapes: Toward a Sounded Anthropology. Annual Review of Anthropology, 39 (1): 329-345.

https://doi.org/10.1146/annurev-

anthro-022510-132230.

Small, Christopher 1984. Music of the Common Tongue: Survival and Celebration in Afro-American Music. London: Calder.

DOMINIQUE SANTOS

LECTURER

ANTHROPOLOGY

RHODES UNIVERSITY

d.santos@ru.ac.za 